\title{
Fish ecology in Lake Banyoles (NE Spain): a tribute to Ramon Margalef
}

\author{
Ramon Moreno-Amich, Quim Pou-Rovira, Anna Vila-Gispert, Lluís Zamora \\ \& Emili García-Berthou
}

Institut d'Ecologia Aquàtica, Universitat de Girona, E-17071 Girona, Catalonia, Spain.

Corresponding autor: emili.garcia@udg.es

\begin{abstract}
Lake Banyoles is the second largest lake in the Iberian Peninsula and due to this relative uniqueness, its peculiar geological origin, and its considerable age attracted the early attention of the late Professor Ramon Margalef. One of the first papers by Margalef was on the biota of Lake Banyoles and two of the first four Ph.D. theses that he supervised were about the limnology of this lake. Unfortunately, the uniqueness of this lake also implied that it was the first place of introduction into the Iberian Peninsula of several exotic fish species, early in the XXth Century and nowadays the lake fish assemblage is dominated by invasive species, and some native ones have been extirpated. Although the limnological studies in Lake Banyoles were pioneering within the Iberian Peninsula, studies on fish ecology of the lake did not start until 1989. Thereafter, four Ph.D. theses have been completed on different aspects of the fish assemblages of Lake Banyoles. The aim of this paper is to provide a short overview of this research, largely brought about by the considerable limnological information previously available for this lake, thanks to the insightful, pioneering work of Professor Margalef.
\end{abstract}

Keywords: Lake Banyoles, fish ecology, Iberian Peninsula, invasive species, Ramon Margalef.

\section{RESUMEN}

El lago de Banyoles es el segundo mayor lago de la Península Ibérica y debido a su relativa singularidad, su peculiar origen geológico y su considerable edad atrajo la atención temprana del fallecido profesor Ramon Margalef. Uno de las primeras publicaciones de Margalef fue sobre la biota del lago de Banyoles y dos de las primeras cuatro tesis doctorales que dirigió fueron sobre la limnología del lago. Desgraciadamente, la singularidad de este lago implicó también que fue el primer lugar de introducción en la Península de varias especies exóticas de peces, a principios del siglo XX, y actualmente la comunidad de peces está dominada por especies invasoras y algunas nativas han sido extirpadas. Aunque los estudios limnológicos en el lago fueron pioneros en la península ibérica, la ecología de peces no se empezó a estudiar hasta 1989. Posteriormente, se han completado cuatro tesis doctorales sobre distintos aspectos de las comunidades de peces del lago de Banyoles. El objetivo de este artículo es proporcionar una breve sinopsis de estas investigaciones, que en gran medida surgieron de la considerable información limnológica existente sobre el lago, gracias al trabajo pionero y visionario del profesor Margalef.

Palabras clave: lago de Banyoles, ecología de peces, Península Ibérica, especies invasoras, Ramon Margalef.

\section{INTRODUCTION}

Lake Banyoles is the second largest lake in the Iberian Peninsula, a region with few lowland lakes. The relative uniqueness of this lake, its peculiar geological origin (mixed tectonic-karstic lake), and its considerable age attracted the early attention of the late Professor Ramon Margalef, Spain's most important ecologist (Ros, 2004; Herrera, 2005; see also Ros, 1991; Durfort, 2005; and http://www.icm.csic.es/bio/ personal/fpeters/margalef/margalef.htm for obituaries and further biographic info). One of the first papers of Margalef was on the biota of Lake Banyoles (Margalef, 1946) and two of the first four Ph.D. theses that he supervised were on the limnology of Lake Banyoles (Planas, 1973; Miracle, 1976). Unfortunately, the uniqueness of Lake Banyoles also implied that it was the first place of introduction into the Iberian Peninsula of several exotic fish species, early in the XXth Century and nowadays the lake fish assemblage 
is dominated by widespread exotic fish and some native species have been extirpated. Although the limnological studies in Lake Banyoles were pioneering within the Iberian Peninsula, the study of its fish ecology did not start in Banyoles until 1989. Thereafter, four Ph.D. theses (GarcíaBerthou, 1994; Vila-Gispert, 1996; Pou-Rovira, 2004; Zamora, 2004) have been completed on different aspects of the fish assemblage of Lake
Banyoles, under the supervision of the first author of the present paper. The aim of this paper is to provide a short overview of this research, which has been mostly published elsewhere. Our interest in this research area emerged to a large extent due to the considerable information that was available on the limnology of Lake Banyoles, thanks to the insightful, pioneering work of Professor Margalef.
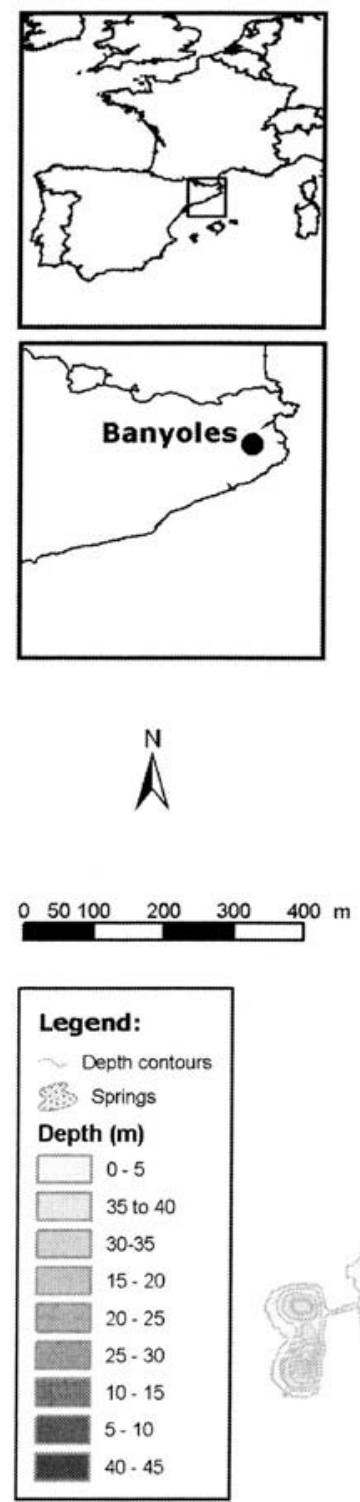

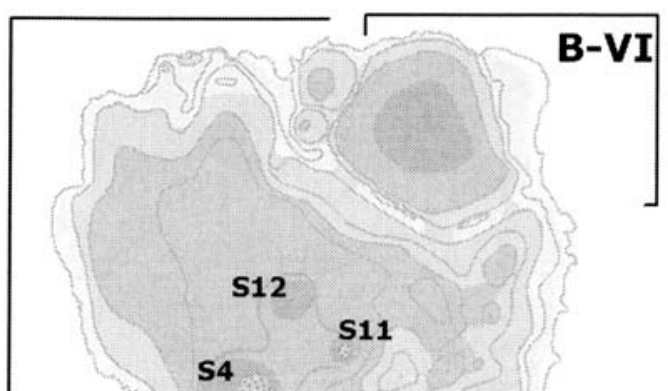

S4

\section{B-IV}

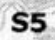

S5

B-V

\$3

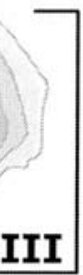

S6

B-III

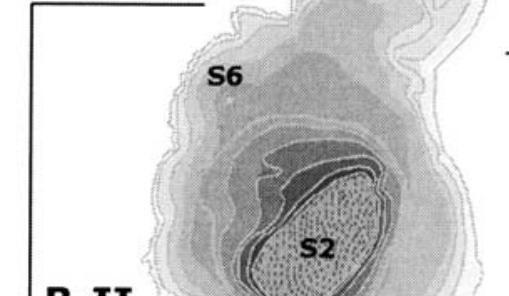

\section{B-II}

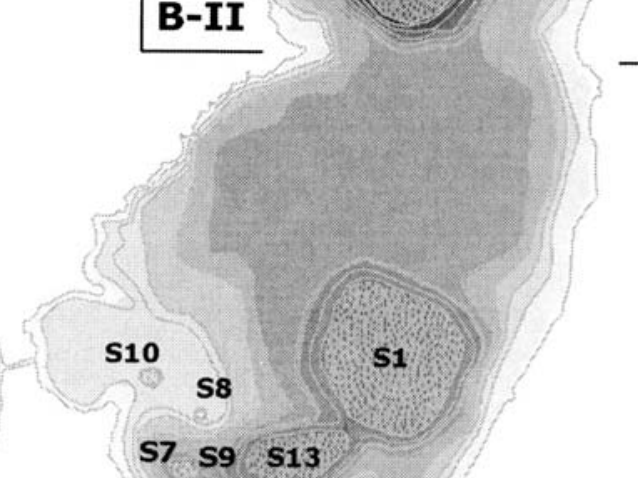

\section{B-I}

Figure 1. Location of Lake Banyoles in the Iberian Peninsula (left) and bathymetric map (right). Localización del lago de Banyoles en la Península Ibérica (izquierda) y su respectivo mapa batimétrico (derecha). 


\section{STUDY AREA}

Lake Banyoles, situated at $42^{\circ} 7^{\prime} \mathrm{N}, 2^{\circ} 45^{\prime} \mathrm{E}$ and $172 \mathrm{~m}$ above sea level in Catalonia, Spain (Fig. 1), is of mixed tectonic-karstic origin. The mainly subterranean water sources and high calcium concentration restrict its productivity. Although usually considered oligotrophic because of the low nutrient concentration and phytoplankton biomass, it is rather mesotrophic based on its primary production and its benthic community. A number of studies have been carried out on its morphometry (Moreno-Amich \& García-Berthou, 1989), hydrology (Casamitjana \& Roget, 1993), bacterioplankton (Garcia-Gil et al., 1996), phytoplankton (Planas, 1973), zooplankton (Miracle, 1976) and non-littoral zoobenthos (Prat \& Rieradevall, 1995). Selected features of the lake are: surface area, 111.8 ha; mean depth, $14.8 \mathrm{~m}$; water temperature, $7-26^{\circ} \mathrm{C}$; and conductivity, $900-2000 \mu \mathrm{S} \mathrm{cm}^{-1}$. Three diffe-

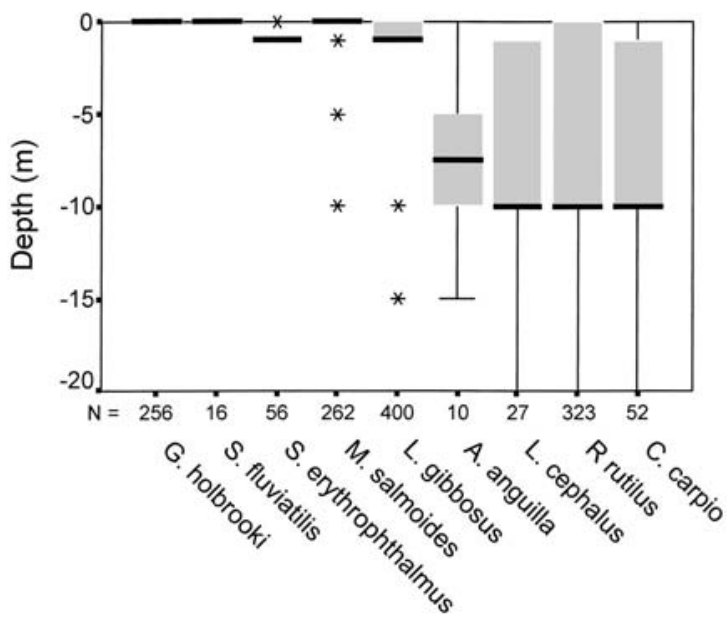

Figure 2. Box plots of the capture depth of the different fish species. The box (grey rectangle) corresponds to the 25th and 75 th percentiles, the dark line inside the box represents the median depth (50\% of the individuals), error bars are the minimum and maximum except for outliers (asterisks corresponding to values beyond 1.5 boxes from the box). The figures (above the species name) are the number of fish captured. Gráficas de caja para la profundidad de captura de las distintas especies de peces. La caja (rectángulo gris) corresponde a los percentiles 25 y 75, la línea oscura dentro de la caja representa la profundidad mediana (50\% de los individuos), las barras de error el mínimo y máximo exceptuando los valores atípicos (asteriscos que corresponden a valores a más de 1,5 cajas de distancia de la caja). Los valores encima del nombre de la especie son el número de peces. rent littoral habitats were distinguished for fish sampling, corresponding to the plant associations described by Bolòs \& Masalles (1983) and characterised by: 1) reed, Phragmites australis ssp. australis, dominating the western shore; 2) cattail, Typha angustifolia ssp. australis and Typha latifolia; and 3) rush, Schoenoplectus littoralis, dominating the zones 1-2 $\mathrm{m}$ deep and more common around the eastern shore.

\section{FISH ECOLOGY OF LAKE BANYOLES}

Historical fish records from Lake Banyoles have been described elsewhere (García-Berthou \& Moreno-Amich, 2000a). The fish assemblage before 1910 comprised chub, Leuciscus cephalus (L.), Mediterranean barbel, Barbus meridionalis Risso, freshwater blenny, Salaria fluviatilis (Asso), eel, Anguilla anguilla (L.), and threespined stickleback, Gasterosteus aculeatus L. Up to 12 fish species have been introduced into the lake over the past 100 years, resulting in a decline of five/six native species; the tench, Tinca tinca (L.), being an anomaly having possibly been introduced several centuries ago (see García-Berthou \& Moreno-Amich, 2000a). Three-spined stickleback and tench disappeared around 1960; eel and barbel are now very rare.

The lake is nowadays dominated by introduced species. In the littoral zone, the most common fish species were largemouth bass, Micropterus salmoides (Lacépède), and pumpkinseed sunfish, Lepomis gibbosus (L.) (Fig. 2). Pumpkinseeds were particularly abundant in rush beds, whereas largemouth bass were more abundant in shallower, more vegetated habitats. This distribution pattern matches that of their main prey, amphipods (García-Berthou \& Moreno-Amich, 2000b) and Atyaephyra desmaresti (García-Berthou, 2002).

The limnetic zone is dominated by roach, Rutilus rutilus (L.) and it is also inhabited by common carp, Cyprinus carpio L., chub, and eel (Figs. 2 and 3). The size structure is dominated by large fish, particularly carp, chub, and eel, and there is a lack of younger size groups suggesting recruitment problems (García- 


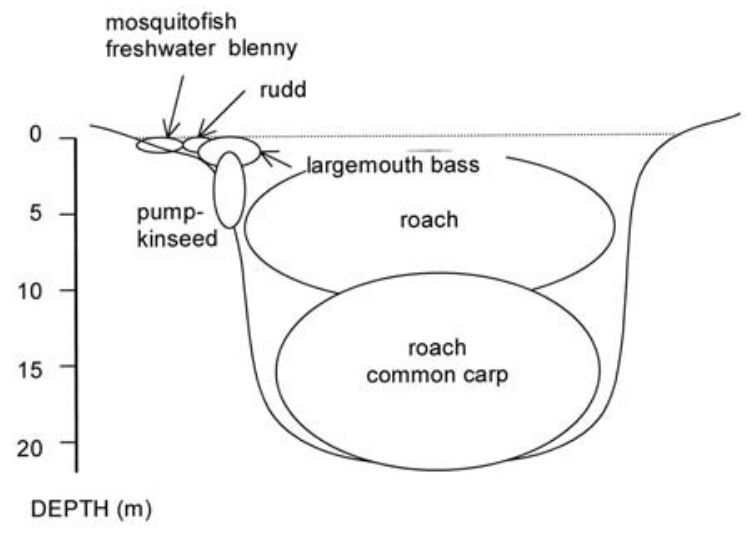

Figure 3. Conceptual diagram of the habitat of the main fish species habiting the lake in 1989-1991. Diagrama conceptual del hábitat de las principales especies de peces presentes en el lago en 1989-1991.

Berthou \& Moreno-Amich, 2000a). Roach is the main zooplanktivorous fish in the lake, mostly preying on the cladoceran Daphnia longispina (García-Berthou, 1999a), whereas carps are benthic feeders (García-Berthou, 1994). Although eel and chub were mostly captured in deep waters (Fig. 2), their gut contents consisted of large, littoral prey (crayfish and amphibians, respectively) (García-Berthou, 1994), suggesting that they fed in the littoral zone at night.

\section{LIFE-HISTORY STRATEGIES}

Seven life-history traits were used to describe the life-history strategies of 12 native and introduced species from a permanent lake in Catalonia. We also determined if life-history strategies could explain the success of fish species in this ecosystem, and analyse differences in lifehistory traits between native and introduced species to determine which life-history traits are characteristics of successful invasive species.

Data were obtained for the following 7 lifehistory traits: (1) mean generation time (in months), (2) length of breeding season (in months), (3) spawning mode categorized as: 1- single spawning per year, 2- from two to four spawnings per year, and 3- more than four spawnings per year, (4) fecundity as the average number of vitellogenic oocytes of mature females in a single spawning season, (5) mean oocyte size as the mean diameter of the largest oocytes in mature ovaries (to nearest $0.01 \mathrm{~mm}$ ), (6) parental care quantified as the sum of $\mathrm{A}+\mathrm{B}+\mathrm{C}+\mathrm{D}$ following Winemiller (1989), being: $A=$ special placement of zygotes (1), or zygotes and larvae (2); $\mathrm{B}=$ brief period of nutritional contribution to larvae (2), or long period of contribution to larvae or embryos (4); $\mathrm{C}=$ brief period of parental protection by one sex (1), or both (2), or long period of parental protection by one sex (2), or both (4); $\mathrm{D}=$ very long period of gestation (4), (7) maximum fork length (FL) reported in millimetres. Maximum length rather than mean length of mature adults was used in analyses, since it better reflects genetic potential among fish exhibiting indeterminate growth. Estimates of fish lifehistory traits were obtained from our own data already published (Vila-Gispert, 1996; VilaGispert \& Moreno-Amich, 1998; Vila-Gispert \& Moreno-Amich, 2000) and complemented from literature sources (Table 1).

A principal component analysis (PCA) was computed from the correlation matrix derived from 12 fish species and all 7 life-history traits in the original data set (Table 1). The ordination of species based on PCA showed differences in life-history strategies among fish species from Lake Banyoles (Fig. 4). Clustering of the species based on Euclidean distances allowed us to group the species into two major groups (Fig. 5): (1) species with one or few spawnings per year, short breeding season, long generation time, large size, high fecundity, and no parental care (Fig. 4). This set of life-history traits corresponded to the periodic life-history strategy described by Winemiller (1989) and Winemiller \& Rose (1992), and (2) species with multiple spawnings per year, prolonged breeding season, short generation time, small size, low fecundity, parental care, and small to medium size of eggs. This association of lifehistory traits corresponded to the opportunistic life-history strategy described by Winemiller (1989) and Winemiller \& Rose (1992). The absence of equilibrium life-history strategists could be related to the climatic conditions of 
Table 1. Life-history traits of fish species from Lake Banyoles. Spawning mode was categorized as: 1- single spawning per year, 2- from two to four spawnings per year, and 3- more than four spawnings per year; parental care was quantified as the sum of $\mathrm{A}+\mathrm{B}+\mathrm{C}+\mathrm{D}$ following Winemiller (1989): A= special placement of zygotes (1), or zygotes and larvae (2); B= brief period of nutritional contribution to larvae (2), or long period of contribution to larvae or embryos (4); $\mathrm{C}=$ brief period of parental protection by one sex (1), or both (2), or long period of parental protection by one sex (2), or both (4); $\mathrm{D}=$ very long period of gestation (4). Atributos del ciclo vital de las especies de peces del lago de Banyoles. Tipo de puesta categorizada como: 1- una única puesta por año, 2- de dos a cuatro puestas por año, y 3- más de cuatro puesta por año; cuidado parental cuantificado como la suma de $A+B+C+D$ según Winemiller (1989): A= especial emplazamiento de los zigotos (1), o zigotos y larvas (2); $B$ = breve periodo de contribución nutricional a las larvas (2), ó largo periodo de contribución nutricional a las larvas o embriones (4); $C$ = breve período de cuidado parental por parte de uno de los progenitores (1), ó de los dos (2), ó largo período de cuidado parental por parte de uno de los progenitores (2), ó de los dos (4); D=largo periodo de gestación (4).

\begin{tabular}{|c|c|c|c|c|c|c|c|c|c|c|}
\hline Species & Code & $\begin{array}{l}\text { Species } \\
\text { origin }\end{array}$ & $\begin{array}{c}\text { Mean } \\
\text { generation } \\
\text { time } \\
\text { (months) }\end{array}$ & $\begin{array}{l}\text { Length of } \\
\text { breeding } \\
\text { season } \\
\text { (months) }\end{array}$ & $\begin{array}{l}\text { Spawning } \\
\text { mode }\end{array}$ & $\begin{array}{c}\text { Fecundity } \\
\text { (number of } \\
\text { eggs) }\end{array}$ & $\begin{array}{c}\text { Mean } \\
\text { oocyte } \\
\text { size } \\
(\mathrm{mm})\end{array}$ & $\begin{array}{c}\text { Parental } \\
\text { care }\end{array}$ & $\begin{array}{c}\text { Maximum } \\
\text { fork length } \\
\quad(\mathrm{mm})\end{array}$ & Reference \\
\hline Freshwater blenny & BFL & Native & 12 & 3 & 2 & 513 & 0.70 & 3 & 75 & $\begin{array}{l}\text { Viñolas (1986), Vila-Gispert } \\
\text { \& Moreno-Amich }(1998,2002)\end{array}$ \\
\hline Common carp & $\mathrm{CCA}$ & Introduced & 24 & 3 & 1 & 190778 & 1.50 & 1 & 620 & Vila-Gispert (1996) \\
\hline Mosquitofish & GHO & Introduced & 4 & 6 & 3 & 250 & 1.50 & 4 & 50 & Fernández-Delgado (1989) \\
\hline Chub & SCE & Native & 24 & 1 & 1 & 60760 & 1.20 & 1 & 464 & $\begin{array}{l}\text { Vila-Gispert (1996), } \\
\text { Casals (1985) }\end{array}$ \\
\hline Pumpkinseed & LGI & Introduced & 18 & 3 & 2 & 10657 & 1.20 & 3 & 176 & $\begin{array}{l}\text { Vila-Gispert \& } \\
\text { Moreno-Amich }(1998,2000)\end{array}$ \\
\hline Largemouth bass & MSA & Introduced & 28 & 3 & 2 & 25500 & 1.50 & 4 & 506 & $\begin{array}{l}\text { Vila-Gispert (1996), } \\
\text { Winemiller \& Rose (1992) }\end{array}$ \\
\hline Roach & RRU & Introduced & 30 & 1 & 1 & 18519 & 1.20 & 1 & 242 & $\begin{array}{l}\text { Vila-Gispert \& } \\
\text { Moreno-Amich (2000) }\end{array}$ \\
\hline Rudd & SER & Introduced & 24 & 1 & 1 & 36940 & 1.30 & 1 & 259 & $\begin{array}{l}\text { Vila-Gispert \& } \\
\text { Moreno-Amich (2000) }\end{array}$ \\
\hline $\begin{array}{l}\text { Three-spined } \\
\text { stickleback }\end{array}$ & GAC & Native & 12 & 4 & 2 & 100 & 1.70 & 4 & 102 & Winemiller \& Rose (1992) \\
\hline Mediterranean barbel & BME & Native & - & 2 & 1 & 1940 & 2 & 1 & 253 & $\begin{array}{l}\text { Bruslé \& Quignard (2001) } \\
\text { Doadrio (2001) }\end{array}$ \\
\hline Perch & PFL & Introduced & 36 & 0.5 & 1 & 26000 & 2,3 & 1 & 326 & Mann (1978) \\
\hline Pikeperch & SLU & Introduced & 42 & 0.5 & 1 & 260000 & 0.85 & 3 & 860 & $\begin{array}{l}\text { Lehtonen et al. (1996) } \\
\text { Bruslé \& Quignard (2001) }\end{array}$ \\
\hline
\end{tabular}

temperate latitudes that resulted in large scale (cyclic) temporal and spatial variability in ecological conditions that do not favour an equilibrium life-history strategy. In contrast, under these environmental conditions, the periodic life-history strategy was favoured.

It seems that there were not differences in life-history strategies between native and introduced species in Lake Banyoles. Species origin affiliations are not apparent in the general pattern of ordination of species within regions in the plot of species scores on the first two PCA axes (Fig. 4). Both native and introduced species were classified either as opportunistic or periodic. Observed differences in the success of native and introduced species with comparable life-history strategies seem to suggest that the success of fish species in Lake Banyoles could not be explained on the basis of life-history features. Nevertheless, canonical discriminant function analysis (CDF) using species origin as the class variable showed a pattern of higher fecundity, later maturity, and larger size in association with introduced species versus lower fecundity, earlier maturity, and smaller size in association with native species. It seems that successful invasive species in Lake Banyoles display a suite of traits such as high fecundity, late maturity, and large body size. These characteristics may perhaps be viewed 

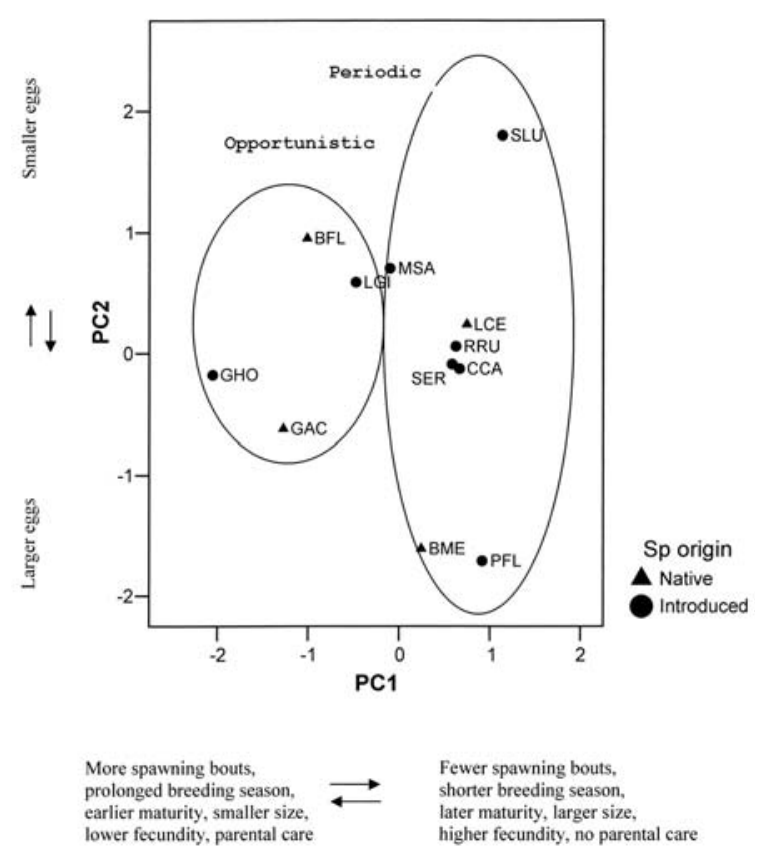

Figure 4. Plot of species PCA scores on the first two principal components of the life-history data of fish from Lake Banyoles. Species codes correspond to those in Table 1. Representación de las puntuaciones discriminantes de las especies de los dos primeros ejes del Análisis de Componentes Principales de los atributos del ciclo vital de las especies del lago de Banyotes. Los códigos de las especies corresponden a los de la Tabla 1. as biological predictors of successful invaders but more information is needed about life-history features of successful introduced species from other ecosystems.

\section{POPULATION ECOLOGY OF LARGEMOUTH BASS}

The largemouth bass (Micropterus salmoides) was introduced during the $1960 \mathrm{~s}$, and it is now one of the dominant species in Lake Banyoles occupying mainly the littoral habitat of the lake (Figs. 2 and 3). This species has been profusely studied in North America from several biology disciplines since several decades ago (Andriano and Clugston, 1975; Philipp and Ridgway, 2002). As a consequence, there is now a lot of published information about largemouth bass, although introduced populations in other continents have received little attention in spite of his wide expansion around the world.

Condition, growth, and demography of largemouth bass, as well as its temporal variations, were studied by Pou-Rovira (2004). With this aim, a survey with ten intensive campaigns and

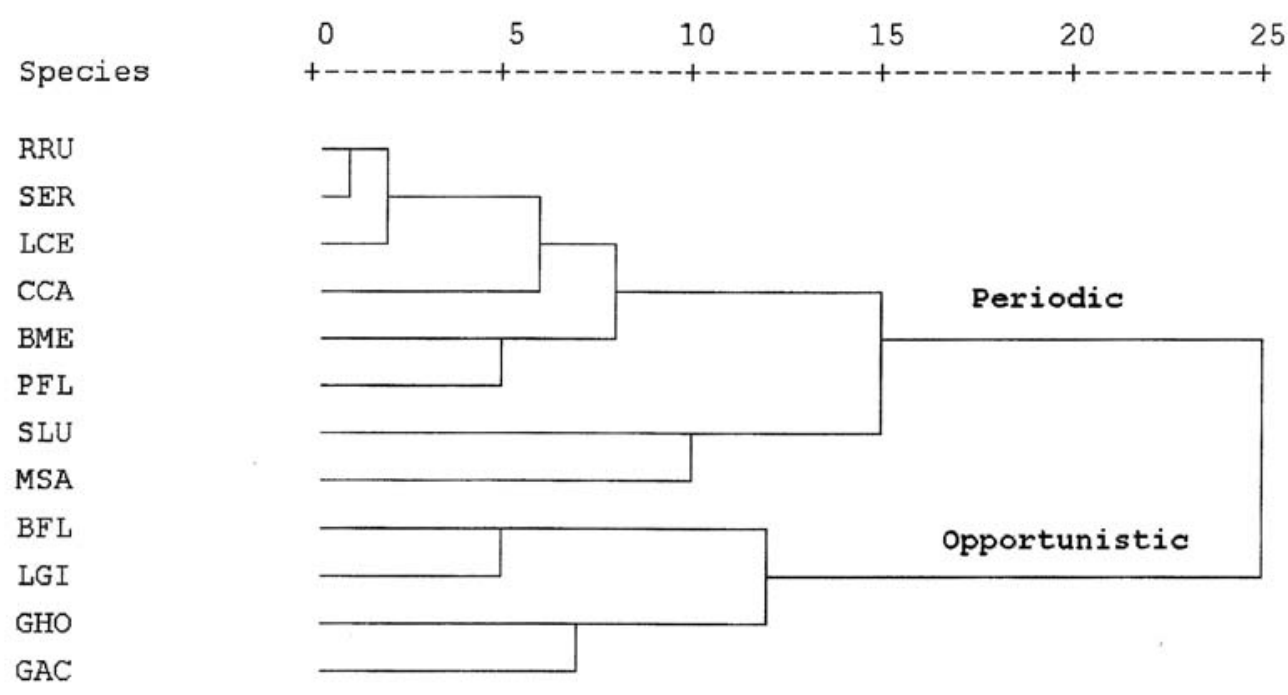

Figure 5. Cluster diagram of fish species from Lake Banyoles based on Euclidean distances computed from seven life-history attributes. Species codes correspond to those in Table 1. Diagrama de cluster para las especies del lago de Banyoles basado en las distancias euclidianas calculadas a partir de siete atributos del ciclo vital. Los códigos de las especies corresponden a los de la Tabla 1. 
some other additional campaigns was designed. This survey began in July 1997 and it lasted until November 1999. Capture was performed by means of a boat electrofishing system specially implemented for this study. This capture technique has proved to be very efficient despite the difficulties of this particular ecosystem. A mark-recapture survey was developed based on fin mutilation and, in some cases, on the use of acrylic dyes for marking. Only in the last campaign (November of 1999) an important part of the capture was sacrificed, in order to extract otholits for age determination.

A wide variety of methods and models have been applied for the data analyses, and for each of the aspects studied, in order to contrast the results and validate its reliability. In the case of the condition, the analysis has been conduced with ANCOVA and related methods, as well as regression and related analyses over lengthweight data. In the study of growth, several models have been fit at length at age data and at observed length increments. Analyses of length frequencies and back calculation have also been used. Finally, for demography description, total abundance and survival have been derived from the mark-recapture models, and after that, several continuous survival models have been fit over those previous estimates. Catchabilities related to the new capture technique have been obtained as well. On the other hand, a survey based on anglers interviews has been implemented in order to determinate the fishing mortality for this population.

The results are summarized in Table 2 . Firstly, they show a slightly lower condition of the largemouth basses of Lake Banyoles when compared with a wide group of other studied populations distributed worldwide. This is probably due to the trophic situation of this lake, usually considered oligo-mesotrophic. Probably related with that, growth is slower than the described average for the species, although maximum and estimated asymptotic lengths are higher. Actually, maximum length observed in Banyoles almost reaches the maximum length described for this species. About the survival pattern, the population studied shows a clear
Table 2. Main population descriptors of largemouth bass (Micropterus salmoides) in Lake Banyoles. Principales descriptores de la población de perca americana (Micropterus salmoides) en el lago de Banyoles.

\begin{tabular}{lc}
\hline Parameters & Values \\
\hline Weight-length relationship & \\
$\log a(\mathrm{~g} / \mathrm{cm})$ & -2.018 \\
$b$ & 3.104 \\
von Bertalanffy growth function & \\
$K\left(\right.$ years $\left.^{-1}\right)$ & 0.161 \\
$L_{\infty}(\mathrm{cm})$ & 66.8 \\
Maximum length $(\mathrm{cm})$ & 57.5 \\
Maximum age $($ years $)$ & 11.8 \\
Mortality & \\
$Z\left(\right.$ years $\left.^{-1}\right)$ & 0.680 \\
$M$ (years $\left.^{-1}\right)$ & 0.314 \\
$F\left(\right.$ years $\left.^{-1}\right)$ & 0.367 \\
\hline
\end{tabular}

ontogenic decrease in mortality, so that its survival curves have always a clearly concave shape, fitting to a III-type of the classical survival patterns proposed by Deevey (Fig. 6). Overall, the results also show a high interannual stability of all the studied aspects, explained by the ambient stability that is typical of this lake ecosystem. That reverts in a high observed longevity that equal the maximum longevity published for the species.

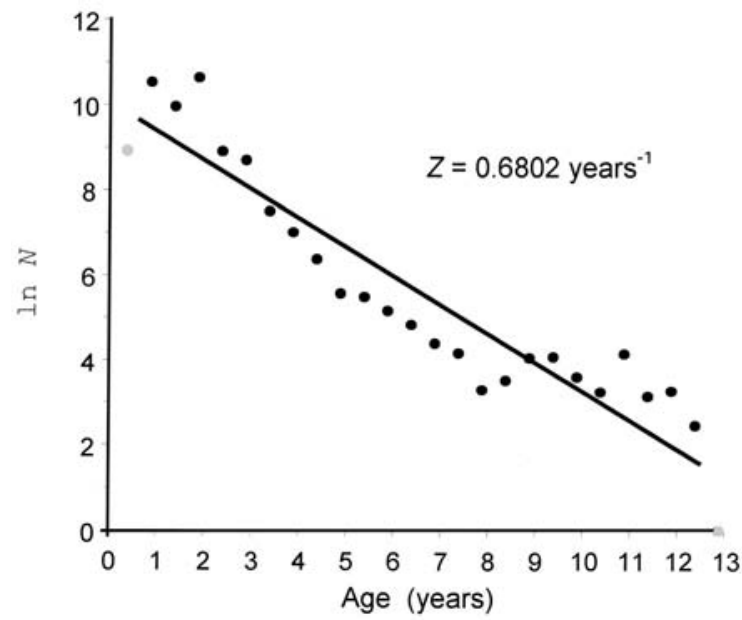

Figure 6. Survival curve of largemouth bass in Lake Banyoles. Curva de supervivencia de la perca americana en el lago de Banyoles. 
At the same time, strong seasonal fluctuations have been described for the condition, growth, and demography. However, these fluctuations have different temporal positions along the annual calendar, suggesting that there is a differentiation between their regulatory factors (Fig. 7). In this way, condition and growth rate exhibit both minimum values around the winter equinox and maximum values around summer equinox, with seasonal oscillations coupled with photoperiod seasonal oscillations, suggesting a clear effect of the duration of the daily activity time. Growth in length stops completely during not less than 3 months in winter. On the other hand, survival rate has oscillations with maximum values in mid winter and minimum values in mid summer, coupled with the oscillations of water and air temperatures. This fact indicates a clear effect of the metabolic rate, probably through the fishing mortality, which depends also on the metabolic rate and has maximum values also in mid summer. All these seasonal fluctuations are highly stable between years, especially in relation to their position into the calendar.
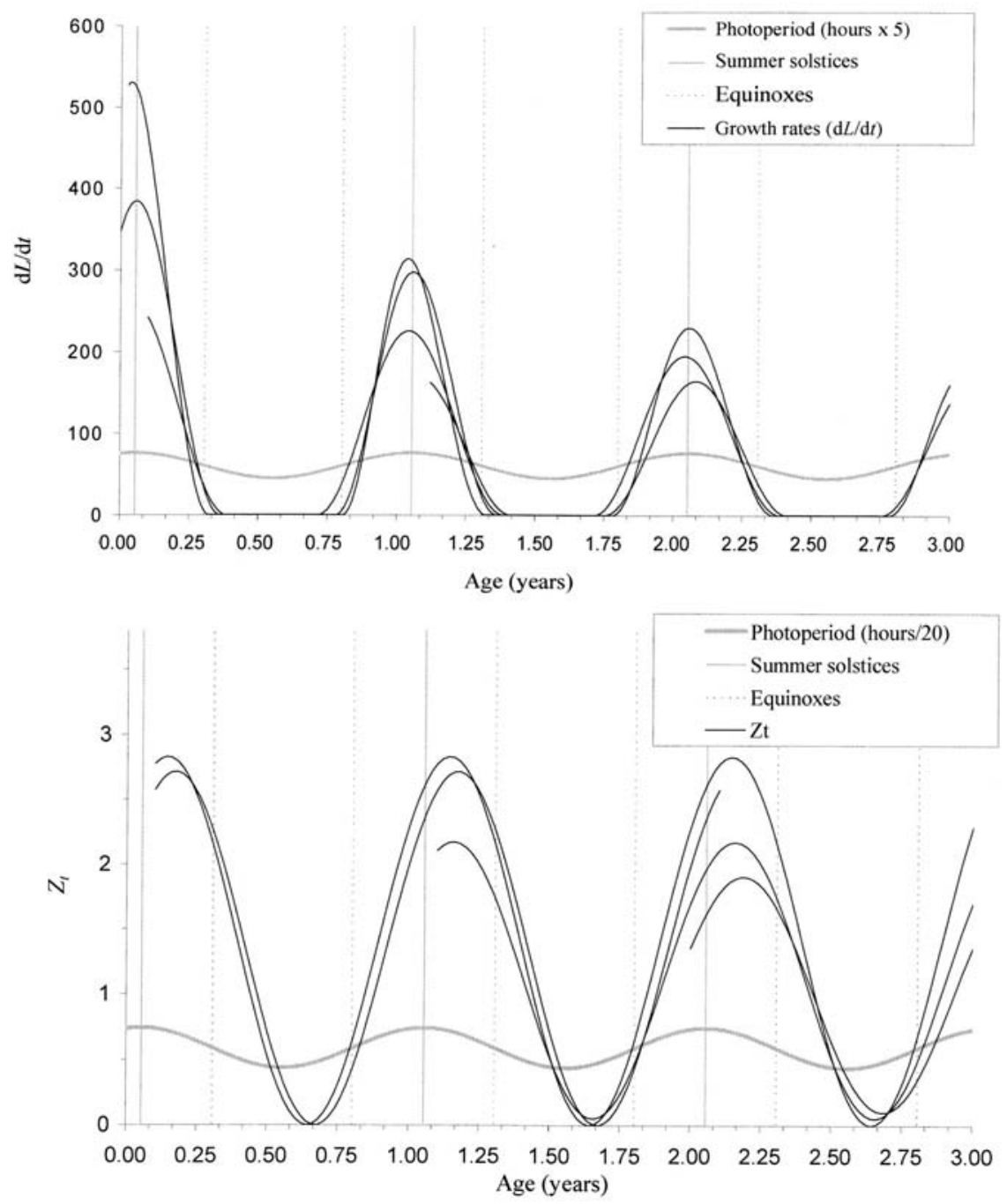

Figure 7. Seasonal oscillations in survivorship rate (above) and mortality (below) of largemouth bass in Lake Banyoles. Oscilaciones estacionales en la tasa de supervivencia (arriba) y la mortalidad (abajo) de la perca americana en el lago de Banyoles. 


\section{HABITAT USE AND SPATIAL DISTRIBUTION}

Habitat use and spatial distribution patterns were analysed by Zamora (2004). The aims of this study were: (1) to describe the habitat use and its seasonal variation, (2) to analyse which environmental factors have a major effect on space utilization, and (3) integrating in one study the littoral and limnetic zones. Fish were captured using a boat mounted electrofishing unit in the littoral zone and trammel nets elsewhere. The boat was equipped with a two-anode-one-cathode set up and a Smith-Root GPP 5.0 model control box. We suspended the two anodes $3 \mathrm{~m}$ apart and $2 \mathrm{~m}$ in front of the boat and used the hull of the aluminium boat for the cathode. All boat electrofishing was conducted in the morning with pulsed DC (60 pulses per second) operating typically at 8-12 A and 300-V. The whole perimeter of the lake was divided in 43 stretches according with different features such as main vegetation, depth, human disturbance or bottom type. For each sample unit, all the fish were cap- tured, processed, and finally released at the same position. Sampling was divided in ten campaigns, between summer 1997 and winter 1999.

The fish community in the littoral zone was dominated by four species that occurred in great abundance, such as largemouth bass $(65.48 \%)$, pumpkinseed (26.73\%), perch $(5.47 \%)$, and carp $(1.43 \%)$. Other catches correspond to perch (Perca fluviatilis), common carp (Cyprinus carpio), and rudd (Scardinius erythrophthalmus). Habitat selection was analysed using both the Manly selection index and analysis of variance. Results showed that juvenile largemouth bass, pumpkinseed sunfish, and perch had a positive selection of habitat, where Schoenoplectus litoralis or Cladium mariscus were dominant. Common carp and rudd presented selection of littoral zones with Typha. Habitat selection seemed to be related with structurally complex environments. Perch and largemouth bass showed temporal variation in habitat distribution and smaller sizes preferred the intermediate vegetation density (Fig. 8). Large bass presented also high site fidelity.

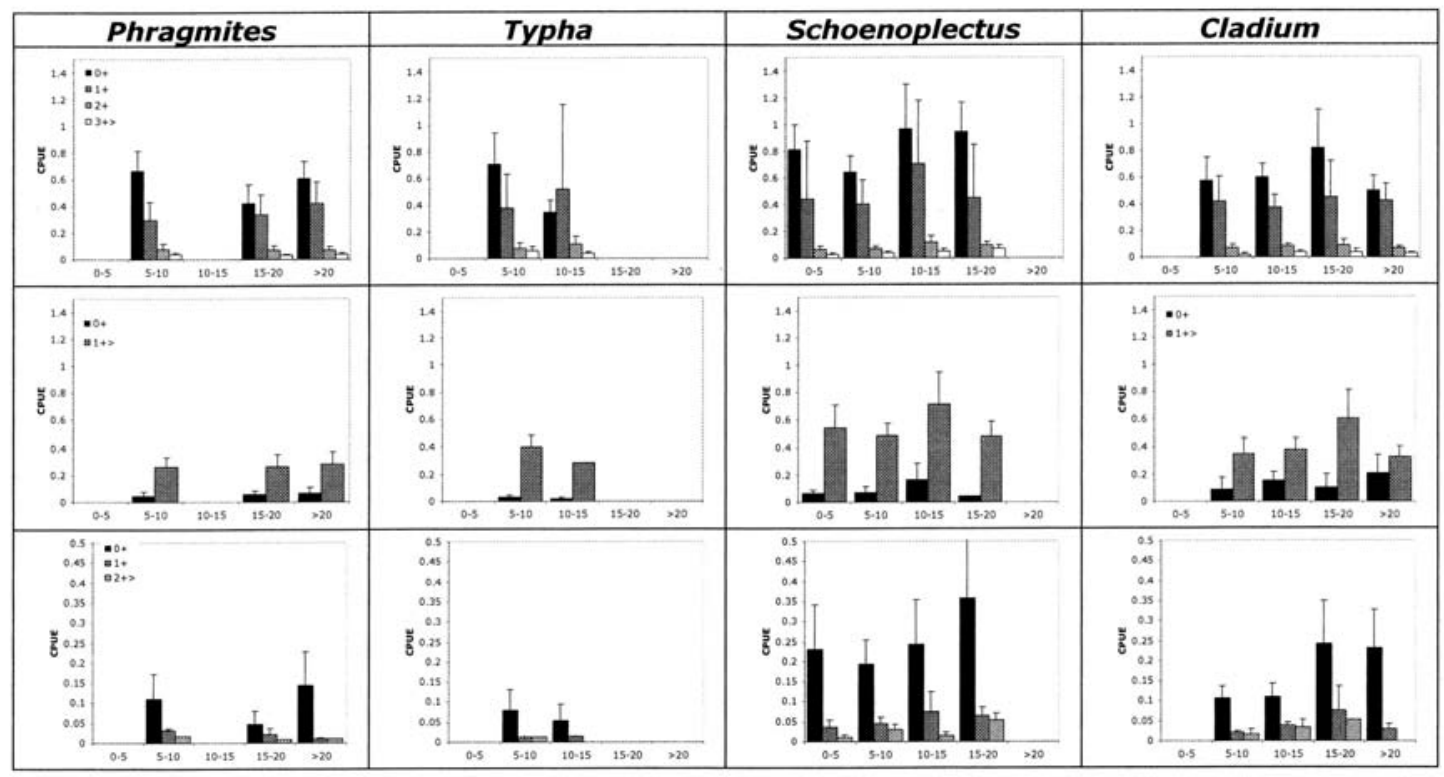

Vegetation density (stems $/ \mathrm{m}^{2}$ )

Figure 8. Relationship of vegetation density $\left(\mathrm{stems} / \mathrm{m}^{2}\right.$ ) of the different habitat categories and abundance (electrofishing CPUE) of largemouth bass, pumpkinseed and perch of different ages in the littoral zone. Relación entre la densidad de vegetación (tallos $/ \mathrm{m}^{2}$ ) de las distintas categorías de hábitat y la abundancia (CPUE a partir de pesca eléctrica) por edades de perca americana, pez sol y perca en la zona litoral. 


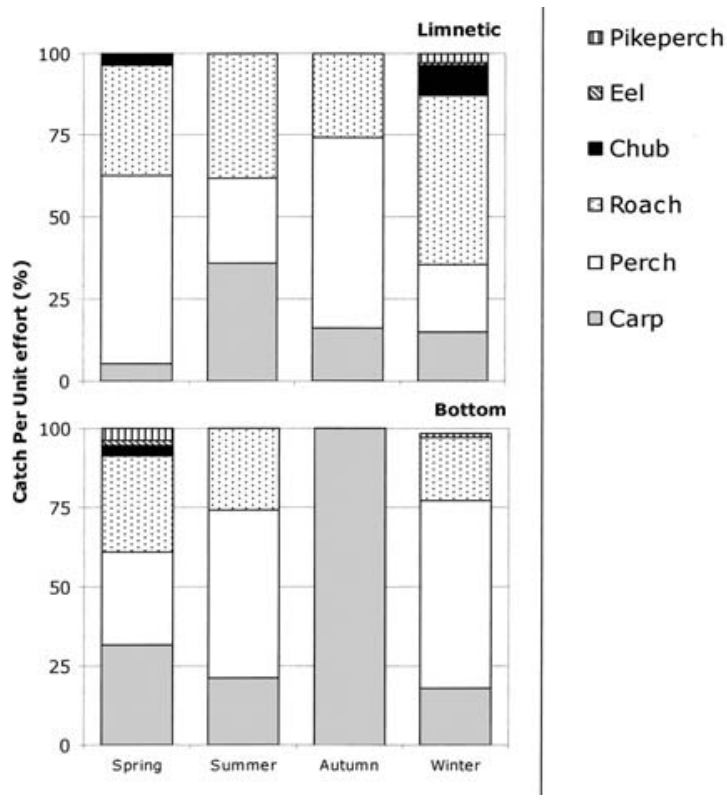

Figure 9. Seasonal relative abundance of captures (CPUE) in the limnetic zone with trammels nets set in limnetic (top figure) and bottom (below) of the lake. Abundancia relativa estacional de las capturas (CPUE) obtenidas en la zona limnética a partir de pescas con redes instaladas en la zona limnética (arriba) y fondo (abajo) del lago.
Fish density and spatial distribution in the limnetic zones was estimated by hydroacoustics. Echosounding surveys were carried out monthly from December 1997 until December 1999, using a Furuno model FE-450 echosounder with a working frequency of $50 \mathrm{kHz}$ and equipped with a single beam transducer $\left(50^{\circ}\right.$ vertical $)$. The acoustic track consisted of 10 transects perpendicular to the coast separated by $200 \mathrm{~m}$ covering the whole lake. All samples were collected during light time. Density maps were obtained with ordinary Kriging for interpolation. Species composition was estimated using nets. Fish were sampled in February, May, August and November 1998, using trammel nets $50 \times 2 \mathrm{~m}$ in size (stretched mesh size: inner net, $2 \mathrm{~cm}$; outer, $12.5 \mathrm{~cm}$ ), mesh size was $7.5 \mathrm{~cm}$. Constant sampling effort was used in different seasons and depths in the limnetic zone $(5,10,15 \mathrm{~m}$ and bottom), setting the nets for $24 \mathrm{~h}$ on six consecutive days. Catch per unit effort (CPUE) was quantified as the number of fish captured per seconds of electrofishing sample and distance (meters) of shoreline. The

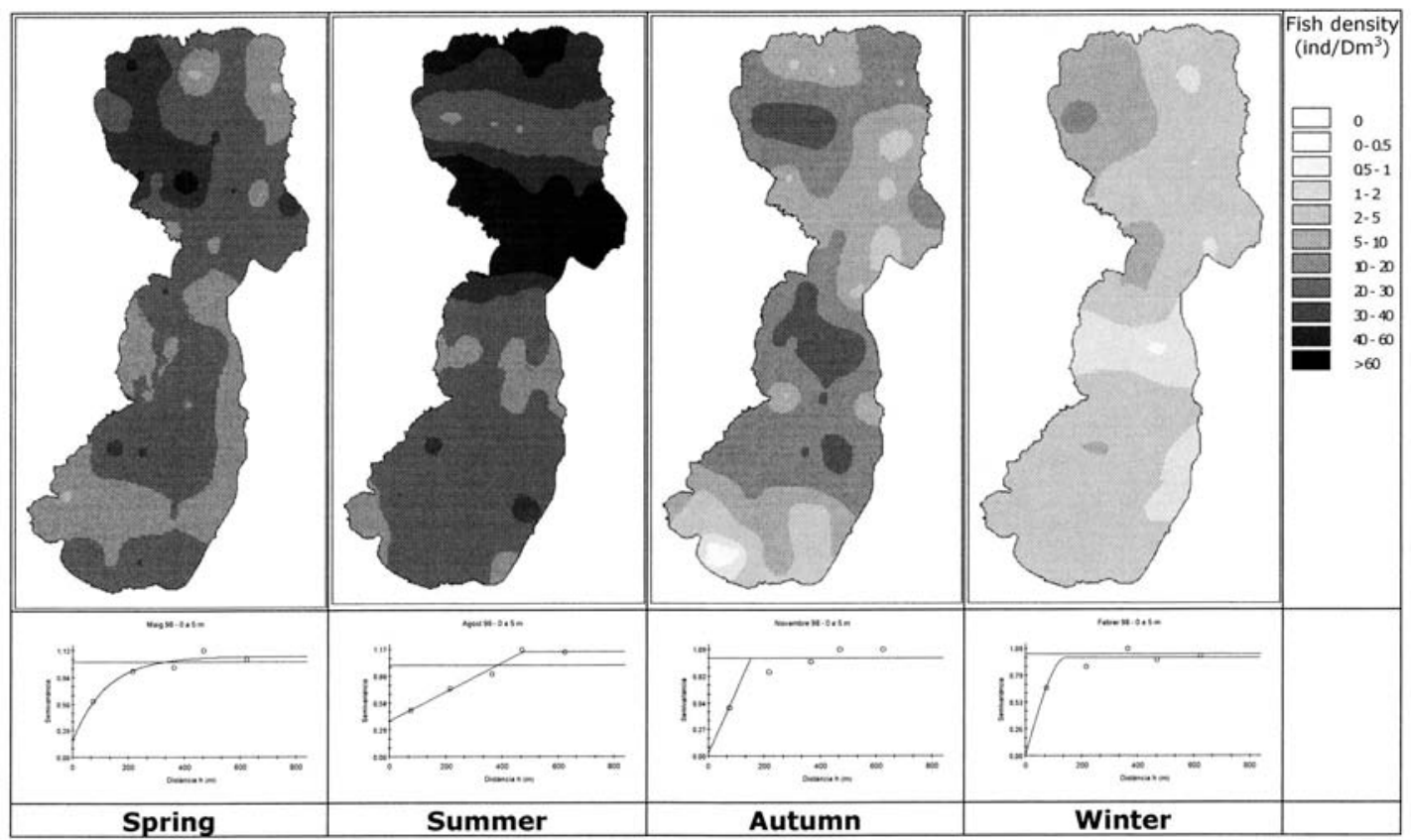

Figure 10. Kriged map of fish acoustic density (ind/ $\mathrm{Dm}^{3}$ ) in 1998 and experimental variograms for the fish abundance standardised to the sample variance. Mapa obtenido por Kriging de la densidad acústica de peces (ind/Dm ${ }^{3}$ ) en 1998 y variogramas experimentales de la abundancia de peces estandarizada en base a la varianza muestral. 
CPUE values were transformed to $\log _{10}(x+1)$ prior to analyses to better meet the assumption of normality. At the laboratory, fish were measured (fork length to the nearest $\mathrm{mm}$ ) and weighed (to the nearest $0.1 \mathrm{~g}$ ). Nine species were caught including perch $(43.8 \%)$, roach (27.8\%), common carp (23.4\%), chub (1.9\%), and pikeperch $(1.5 \%)$. Fish density was maximum in summer and minimum in autumn-winter (Fig. 9). Surface spatial pattern was described using geostatistics (Rivoirard et al., 2000). In winter, fish formed aggregates in the centre of the lake; with the increasing of fish density in summer, the spatial distribution became more homogeneous (Fig. 10). Vertical distribution showed a maximum located at the same depth of the thermocline, between 5 and $8 \mathrm{~m}$. Abundance of different species varied with depth and limnological characteristics of basins. Furthermore, the development of a hydrothermal plume due to underwater inflow increased the turbidity of different parts of the lake altering the distribution of fish that avoid the presence of sediments (Serra et al., 2002).

In order to monitor the movements of perch and chub, 14 individuals were tagged with ultrasonic transmitters (Voegeli \& Pincock, 1996). Movements were followed by means of an automatic system, showing a partition of habitat use between littoral zone and limnetic zone. Fish positions were compiled into a geographic information system database with information on time, deviation, number of pulses, slope and bottom depth (Hooge \& Eichenlaub, 1997). Speed was calculated as a measure of activity and ranges as an estimation of total area occupied.

Tagged perch showed individual variations in activity levels (Zamora \& Moreno-Amich, 2002). All presented a circadian pattern being less active at night (mean speed $0.060 \mathrm{BL} \cdot \mathrm{s}^{-1}$ ) than during the day (mean speed $0.104 \mathrm{BL} \cdot \mathrm{s}^{-1}$ ). They exhibited two peaks of activity at sunrise and sunset respectively (Fig. 11). Two patterns of movement emerged, the first characterised by movement between limnetic and littoral zones, the second restricted to the shoreline. Fish appeared to follow the same path reduc-

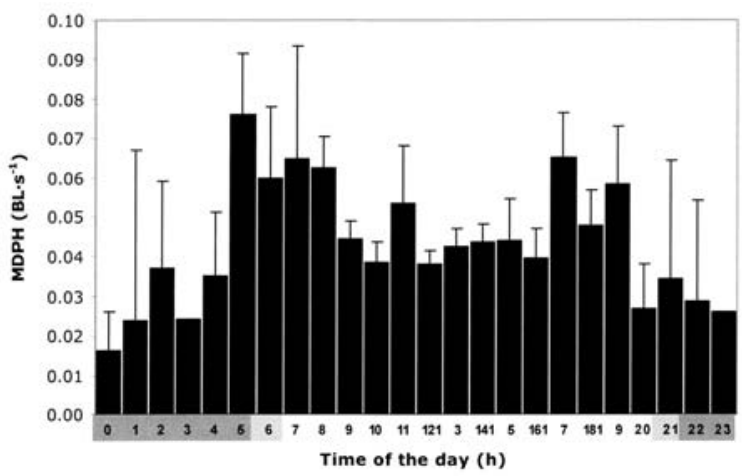

Figure 11. Mean swimming speed of perch tracked during $24 \mathrm{~h}$ cycles (+2 h GMT) measured as the minimum displacement per hour (MDPH). Units are body length per second $(\mathrm{BL} / \mathrm{s})$. Vertical bars denote standard error. The dark and light sections indicate night and day respectively. Grey sections indicate dawn and dusk respectively. Velocidad media de natación de las percas seguidas durante ciclos de $24 h(+2 h$ GMT) medida a partir del desplazamiento mínimo por hora (MDPH). La unidades se expresan como longitud corporal por segundo $(B L / s)$. Las barras verticales representan la desviación típica. La franja horaria oscura indica la noche y la más clara el día. Las secciones grises representan el amanecer y anochecer, respectivamente.

ing the range of movements to a limited part of the lake. Also, fish returned to the same place after movements, showing site fidelity but only for a few days. Overall, although perch could be very abundant in open waters (limnetic zone), they showed a high dependence on littoral waters.

\section{ACKNOWLEDGEMENTS}

We would like to thank everybody who assisted in field and laboratory work, especially Q. Paredes, D. Boix, L. Sunyer, and C. Feo. This study was financially supported by the Town Council of Banyoles, the Autonomous Government of Catalonia (FI fellowships, CIRIT grant AR89, Catalan Government Distinction Award for university research 2004 to EGB), and the Spanish Ministry of Education and Science (PB91-0499). We would like to dedicate this modest paper to the late Professor Margalef, for his enormous legacy to ecological knowledge and its honesty and humility. 


\section{REFERENCES}

ANDRIANO, D. \& J. P. CLUGSTON. 1975. Black bass. Biology and management. National Symposium on the Biology and Management of the Centrarchid Basses.

BOLÒS, O. DE \& R. M. MASALLES. 1983. Mapa de la vegetació de Catalunya. Escala 1: 50000. Memòria del full núm. 33. Banyoles. Barcelona: Generalitat de Catalunya.

BRUSLÉ, J. \& J. P. QUIGNARD. 2001. Biologie des Poissons d'Eau Douce Européens. Techinque \& Documentation, Paris. 625 pp.

CASALS, F. 1985. Biologia i ecologia de Leuciscus cephalus (L., 1758) en el riu Matarranya. M.Sc. Thesis, University of Barcelona, Barcelona. $171 \mathrm{pp}$.

CASAMITJANA, X. \& E. ROGET. 1993. Resuspension of sediment by focused groundwater in Lake Banyoles. Limnol. Oceanogr., 38: 643-656.

DOADRIO, I. 2001. Atlas y libro rojo de los peces continentales de España. Dirección General de Conservación de la Naturaleza, Madrid. 364 pp.

DURFORT, M. (ed.) 2005. Ramon Margalef: sessió en memòria. Sala Prat de la Riba, 5 d'octubre de 2004. Institut d'Estudis Catalans, Barcelona. 92 pp.

FERNÁNDEZ-DELGADO, C. 1989. Life-history patterns of the mosquito-fish, Gambusia affinis, in the estuary of the Guadalquivir River of southwest Spain. Freshwat. Biol., 22: 395-404.

GARCÍA-BERTHOU, E. 1994. Ecologia alimentària de la comunitat de peixos de l'Estany de Banyoles. Ph.D. dissertation, Univ. of Girona, Girona, Spain, 288 pp.

GARCÍA-BERTHOU, E. 1999a. Spatial heterogeneity in roach (Rutilus rutilus) diet among contrasting basins within a lake. Archiv für Hydrobiologie, 146: 239-256.

GARCÍA-BERTHOU, E. 1999b. Food of introduced mosquitofish: ontogenetic diet shift and prey selection. J. Fish Biol., 55: 135-147.

GARCÍA-BERTHOU, E. 2002. Ontogenetic diet shifts and interrupted piscivory in introduced largemouth bass (Micropterus salmoides). International Review of Hydrobiology, 87: 353-363.

GARCÍA-BERTHOU, E. \& R. MORENO-AMICH. 2000a. Introduction of exotic fish into a Mediterranean lake over a 90-year period. Archiv für Hydrobiologie, 149: 271-284.

GARCÍA-BERTHOU E. \& R. MORENO-AMICH. 2000b. Food of introduced pumpkinseed sunfish: ontogenetic diet shift and seasonal variation. J. Fish Biol., 57: 29-40.
GARCÍA-BERTHOU, E. \& R. MORENO-AMICH. 2000c. Rudd (Scardinius erythrophthalmus) introduced to the Iberian peninsula: feeding ecology in Lake Banyoles. Hydrobiologia, 436: 159-164.

GARCÍA-GIL L. J., X. CASAMITJANA \& C. A. ABELLA. 1996. Comparative study of two meromictic basins of Lake Banyoles (Spain) with sulphur phototrophic bacteria. Hydrobiologia, 319: 203-211.

HERRERA, C. M. 2005. Resolution of respect. Ramón Margalef (1919-2004). Bulletin of the Ecological Society of America, 86: 8-11.

HOOGE, P. N. \& W. M. EICHENLAUB. 1997. Animal movement extension to Arcview (2). Anchorage, AK, USA, Alaska Biological Science Center, U.S. Geological Survey.

LEHTONEN, H., S. HANSSON \& H. WINKLER. 1996. Biology and exploitation of pikeperch, Stizostedion lucioperca (L.), in the Baltic Sea area. Ann. Zool. Fennici, 33: 525-535.

MANN, R. H. K. 1978. Observations on the biology of the perch, Perca fluviatilis, in the River Stour, Dorset. Freshwat. Biol., 8: 229-239.

MARGALEF, R. 1946. Materiales para el estudio de la biología del Lago de Banolas (Gerona). Publ. Inst. Biol. apl. Barcelona 1: 27-78.

MIRACLE, M. R. 1976. Distribución en el espacio y en el tiempo de las especies del zooplancton del lago de Banyoles. Monografías ICONA, 5: 1-270.

MORENO-AMICH, R. \& E. GARCÍA-BERTHOU. 1989. A new bathymetric map based on echosounding and morphometrical characterization of the Lake of Banyoles (NE-Spain). Hydrobiologia, 185: 83-90.

PHILIPP, D. P. \& M. S. RIDGWAY. 2002. Black bass: Ecology, conservation, and management. American Fisheries Society, Maryland. 740 p.

PLANAS M. D. 1973. Composición, ciclo y productividad del fitoplancton del lago de Banyoles. Oecologia aquatica 1: 1-106.

POU ROVIRA, Q. 2004. Ecologia demogràfica de la perca americana (Micropterus salmoides) a l'Estany de Banyoles. Ph.D. dissertation, Universitat de Girona. 606 pp. Available online at http://www.tdx.cesca.es/TDX-0214105-093925/

PRAT, N. \& M. RIERADEVALL. 1995. Life cycle and production of Chironomidae (Diptera) from Lake Banyoles (NE Spain). Freshwat. Biol., 33: 511-524.

RIVOIRARD, J., J. SIMMONS, K. G. FOOTE, P. FERNANDES \& N. BEZ. 2000. Geostatistics for estimating fish abundance. Blackwell Science, London. 216 pp. 
ROS, J. D. 1991. Ramon Margalef, limnologist, marine biologist, ecologist, naturalist. Oecologia aquatica, 10: 413-423.

ROS, J. D. 2004. In memory of Ramon Margalef (1919-2004). International Microbiology, 7: 229232.

SERRA, T., J. COLOMER, L. ZAMORA, R. MORENO-AMICH \& X. CASAMITJANA. 2002. Seasonal development of a turbid hydrothermal plume in a lake. Water Research, 36: 2753-2760.

VILA-GISPERT, A. 1996. Estratègies reproductives de les espècies íctiques de les famílies Centrarchidae $i$ Ciprinidae a l'Estany de Banyoles. $\mathrm{PhD}$ thesis. University of Girona, Girona. 289 pp.

VILA-GISPERT, A. \& R. MORENO-AMICH. 1998. Seasonal abundance and depth distribution of Blennius fluviatilis and introduced Lepomis gibbosus, in Lake Banyoles (Catalonia, Spain). Hydrobiologia, 386: 95-101.

VILA-GISPERT, A. \& R. MORENO-AMICH. 2000. Fecundity and spawning mode of three introduced fish species in Lake Banyoles (Catalonia, Spain) in comparison with other localities. Aquat. Sci. 61: 154-166.

VILA-GISPERT, A. \& R. MORENO-AMICH. 2002. Life-history patterns of 25 species from European freshwater fish communities. Envir. Biol. Fish., 65: $387-400$.

VILA-GISPERT, A., R. MORENO-AMICH \& E. GARCÍA-BERTHOU. 2002. Gradients of life-his- tory variation: an intercontinental comparison of fishes. Reviews in Fish Biology and Fisheries 12: 417-427.

VIÑOLAS, D. 1986. Biologia i ecologia de Blennius fluviatilis (Asso 1801) en el riu Matarranya. Ph.D thesis. University of Barcelona, Barcelona. $266 \mathrm{pp}$.

VOEGELI, F. A. \& D. G. PINCOCK. 1996. Overview of underwater acoustics as it applies to telemetry. In: Underwater biotelemetry: Proceedings of the First Conference and Workshop on Fish Telemetry in Europe. E. Baras \& J.C. Phillipart (eds,): 23-30. Liège, University of Liège.

WINEMILLER, K. O. \& K. A. ROSE, 1992. Patterns of life-history diversification in North American fishes: implications for population regulation. Can. J. Fish. Aquat. Sci., 49: 2196-2218.

WINEMILLER, K. O., 1989. Patterns of variation in life-history among South American fishes in seasonal environments. Oecologia, 81: 225-241.

ZAMORA, L. 2004. Distribució espacial i ús de l'hàbitat de la comunitat de peixos a l'estany de Banyoles. Ph.D. dissertation,. Universitat de Girona. 343 p. Available online at http://www.tdx.cesca.es/ TDX-0201105-175924/

ZAMORA, L. \& MORENO-AMICH, R. 2002. Quantifying the activity and movement of perch in a temperate lake by integrating acoustic telemetry and a geographic information system. Hydrobiologia, 483: 219-224. 